\title{
Scholars and Literati at the University of Jena (1558-1800)
}

\author{
David de la Croix \\ Robert Stelter \\ IRES/LIDAM, UCLouvain \\ University of Basel
}

This note is a summary description of the set of scholars and literati who taught at the University of Jena from its inception in 1558 to the eve of the Industrial Revolution (1800).

\section{The UnIVERsity}

The University of Jena was founded at the initiative of the Duke of Saxony, after his defeat in the Schmalkaldic War and consequently the loss of the university in Wittenberg (Hermans and Nelissen 2005). The Alma Mater Jenesis received its deed of foundation from the German imperator in August 1557. Teaching started one year later. From the beginning, the University of Jena had a sharp Lutheran character and was one of the most politically radical universities in Germany. At the turn of the 19th century, the University flourished and emerged as a center of German idealism and early Romanticism that attracted some of the most influential scholars of the time.

\section{SOURCES}

On the occasion of its 300th anniversary in 1858, Günther (1858) published a Festschrift on the University of Jena. The Festschrift is a compendium of brief biographies of all scholars by faculty, up to the year 1858 . With almost 300 pages this comprehensive book serves as the main source. We were only able to add a marginal number of scholars who were missing in Günther (1858), from a variety of other sources.

\section{SOME STATISTICS}

Table 1 shows some descriptive statistics. There are 370 scholars and literati. The year of birth is known, sometimes approximatively, for 342 of them. The mean age at appointment is 32.9 years, and fluctuated quite a bit. Longevity did not improve over time and remained around 60 years, which is low compared to other universities. The birth place is known for $95 \%$ of the individuals. The median distance between birth and the Alma Mater fenesis is $90 \mathrm{~km}$, with less than $12 \%$ of scholars born in Jena. It does not display a time trend. Finally, $72 \%$ of the scholars have a Wikipedia page (in some language), and $91 \%$ of them have left a footprint in the catalogues of the libraries of the world, Worldcat, either by having published some work, or by having been the subject of published books and articles. Those two numbers are very high, a reflection of the fact that our sample is mostly built from the list of full professors in Günther (1858).

\section{FIELDS}

Figure 1 shows the relative importance of fields, broadly defined. The fields of knowledge reflect the four faculties of the full University of Jena: Theology, Medicine, Law and Humanities. Due to its humanistic importance towards the end of the 18th century, most of the scholars are linked to the faculty of Humanities. Even though no separate faculty of sciences existed over the period considered, we identified some mathematicians, physicists and so on as scholars linked to science. 


\begin{tabular}{|c|c|c|c|c|c|c|}
\hline \multicolumn{2}{|c|}{ Period } & \multirow{2}{*}{$\begin{array}{l}\text { nb. } \\
\text { obs }\end{array}$} & \multirow{2}{*}{$\begin{array}{l}\% \text { birth year } \\
\text { known }\end{array}$} & \multirow{2}{*}{$\begin{array}{l}\text { mean age } \\
\text { at appoint. }\end{array}$} & \multirow{2}{*}{$\begin{array}{c}\text { mean age } \\
\text { at death }\end{array}$} & \multirow{2}{*}{$\begin{array}{l}\text { life exp. } \\
\text { at } 30\end{array}$} \\
\hline Start & End & & & & & \\
\hline 1527 & 1617 & 113 & 80.5 & 34.3 & 59.1 & 58.3 \\
\hline 1618 & 1685 & 77 & 98.7 & 31.4 & 59.8 & 60.6 \\
\hline 1686 & 1733 & 58 & 96.6 & 36.7 & 64.9 & 66.2 \\
\hline 1734 & 1800 & 122 & 97.5 & 31.1 & 59 & 59.3 \\
\hline 1000 & 1800 & 370 & $92 . \overline{4}$ & 32.9 & $60 . \overline{2}$ & 60.1 \\
\hline & & & $\begin{array}{c}\% \text { birth place } \\
\text { known }\end{array}$ & $\begin{array}{l}\text { median distance } \\
\text { birth-institution }\end{array}$ & $\begin{array}{c}\% \text { with } \\
\text { Wikipedia }\end{array}$ & $\begin{array}{c}\% \text { with } \\
\text { Worldcat }\end{array}$ \\
\hline 1527 & 1617 & & 91.2 & 105 & 61.9 & 78.8 \\
\hline 1618 & 1685 & & 100 & 84 & 81.8 & 96.1 \\
\hline 1686 & 1733 & & 91.4 & 67 & 70.7 & 98.3 \\
\hline 1734 & 1800 & & 97.5 & 86 & 74.6 & 96.7 \\
\hline 1000 & 1800 & & $\overline{95 . \overline{1}}$ & 90 & $\overline{7} \overline{1} . \overline{6}$ & 91.4 \\
\hline
\end{tabular}

Table 1: Summary statistics by period

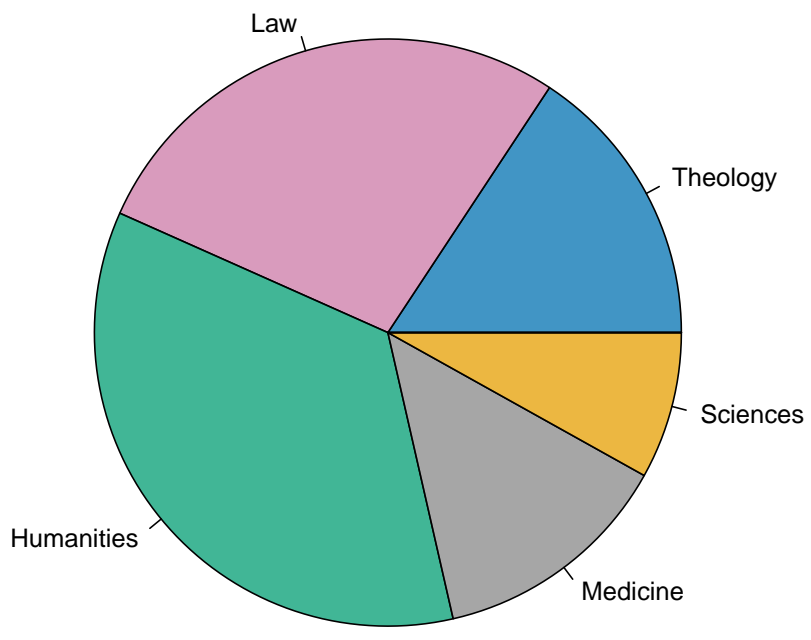

Figure 1: Broad fields at University of Jena 


\section{Place OF BIRTH}

Figure 2 is a plot of the places of birth of all the scholars of Jena, and shows the Germanic character of this university.

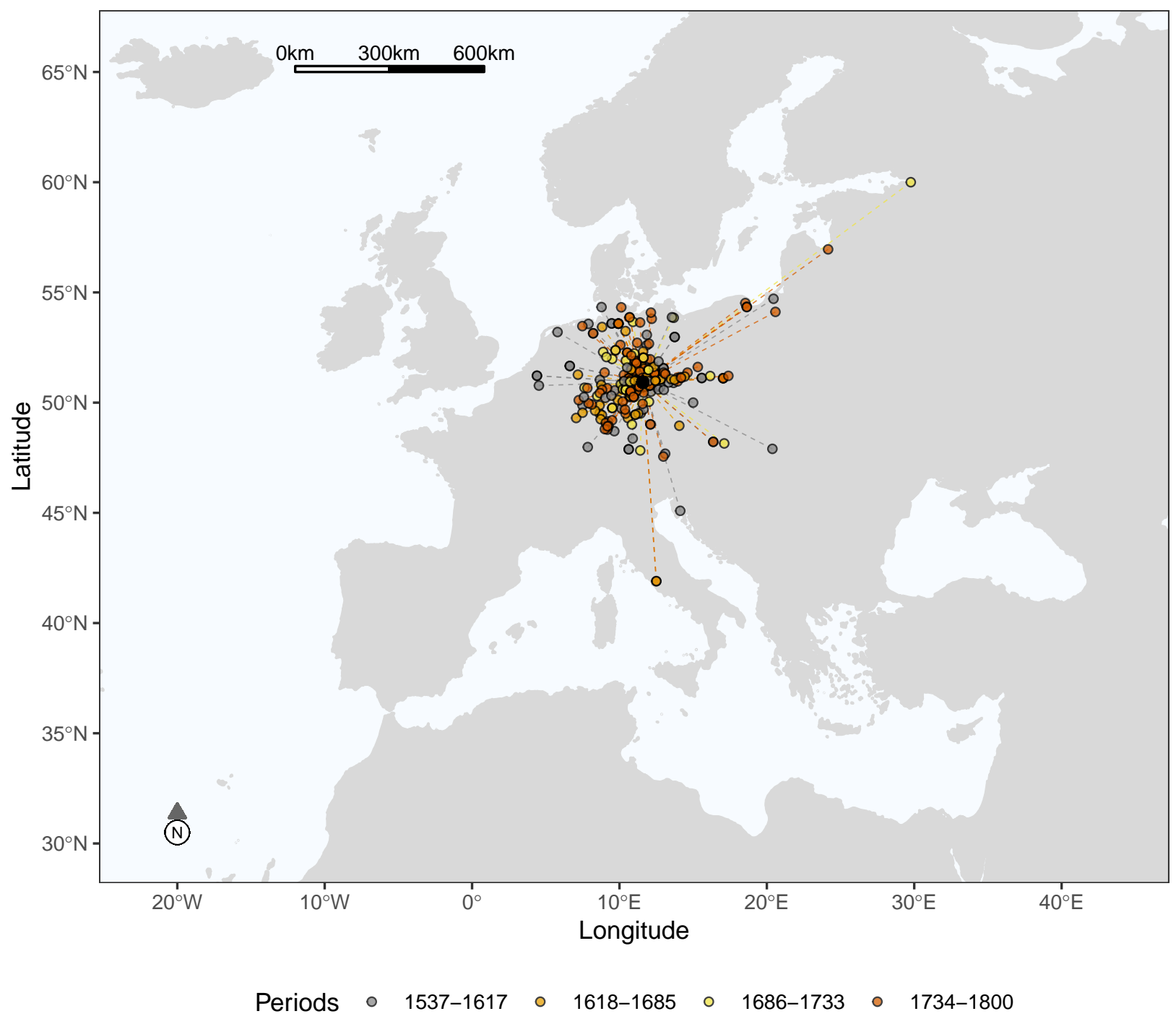

Figure 2: Place of birth of the scholars and literati at the University of Jena

\section{HUMAN CAPITAL OF SCHOLARS AND LITERATI}

For each person in the database we compute a heuristic human capital index, identified by combining information from Worldcat and Wikipedia using a principal component analysis. We also compute the notability of the university at each date by averaging the human capital of the scholars active in Jena 25 years before that date. Details are given in Appendix. Figure 3 shows the names of all the scholars with a positive human capital index. The orange line plots the notability of the university. The vertical green lines (rug plot) show the distribution of all scholars, including the obscure ones.

The pattern is one of a very good university through the period considered. Exceptional scholars are present at the end of the period, but it is not yet reflected in the notability of the university. It is not just von Schiller, but a concentration of several exceptional persons who make Jena so exceptional at the end of the eighteenth century. 


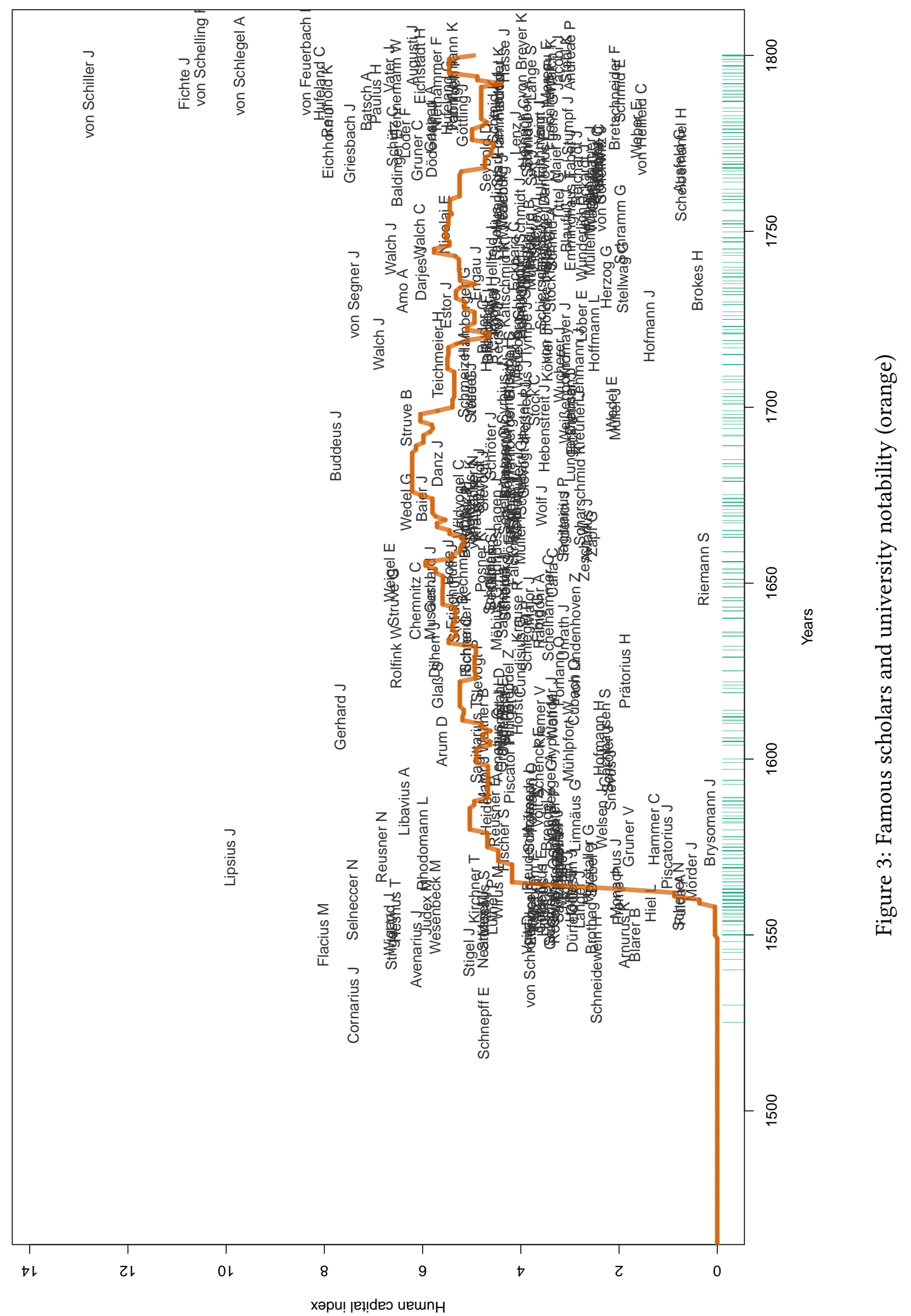




\section{TOP 5 PROFESSORS}

We now provide a brief overview of the five professors with the highest human capital index.

Johann Christoph Friedrich von Schiller (Marbach (Neckar) 1759 - Weimar 1805), present-day eponym of the university, was a physician, philosopher and historian. He studied law and graduated in 1780 with a doctoral degree in medicine at Karl's High School. After escaping military service, he focused on his passion: writing dramas, poets and ballads. Leaving an impressive life work, he is one of the most important German dramatists and poets. He started to teach at the faculty of Philosophy in 1789 .

Johann Gottlieb Fichte (Rammenau 1762 - Berlin 1814) belongs to the most important thinkers in the philosophical movement of German idealism. New insights into the nature of consciousness as well as works on the Thesis-Antithesis-Synthesis are among his key contributions to epistemology. However, he is sometimes considered as one of the fathers of German nationalism and his writings include some anti-Semitic elements. In 1794 he obtained an academic position at the University of Jena, and, after 1800, at the universities of Erlangen and Berlin.

Friedrich Wilhelm Joseph von Schelling (Leonberg 1775 - Ragaz 1854), had a background in theology, philosophy, medicine and mathematics that enabled him to contribute to and renew natural philosophy. He also belonged to the main thinkers in the German idealism movement and bridged Kant's and Hegel's philosophies. He studied in Tübingen and Leipzig and entered the University of Jena in 1798. He left in 1803 to move to Würzburg and later moved to Munich and Berlin.

Justus Lipsius (Overijse 1547 - Louvain 1606) studied theology, law and humanities. The classical philologist and humanist created the intellectual movement of Neostoicism by reviving ancient stoicism in a way that aims to be compatible with Christianity. He switched between Catholicism and Protestantism back and forth and held academic positions in Louvain, Jena and Leiden. He had lively exchanges with his contemporaries, writing around 4000 letters. The building of the European Parliament in Brussels is named after him.

August Wilhelm von Schlegel (Hannover 1767 - Bonn 1845) shaped the Early German Romanticism. Studying theology and classical studies, he became a well-known translator and scholar of language and literature. After a first academic position in Jena, he travelled across Europe, giving lectures, e.g. in Berlin and Vienna, and was finally appointed as first professor of Indology at the newly established university in Bonn. His translations of Shakespeare's writings are among his main contributions.

\section{RELATED SCHOLARS}

Beyond those who taught at Jena, several important individuals are related to the University. They probably did not occupy an official position, but they were involved in teaching and/or research. Those scholars are counted to establish all figures but Figure 3. Here, we present one exceptional person in that category.

Georg Ernst Stahl (Ansbach 1660 - Berlin 1734). From 1679 he was a student of medicine and chemistry in Jena. In 1684 he also did his PhD there. Applebaum(2003) claims he then lectured in chemistry there. After his ph.D he made his habilitation and pursued his academic career at the University of Halle. He is well known for having contributed to chemistry and to medicine, defending new viewpoints in these two fields (phlogiston theory and vitalism). 


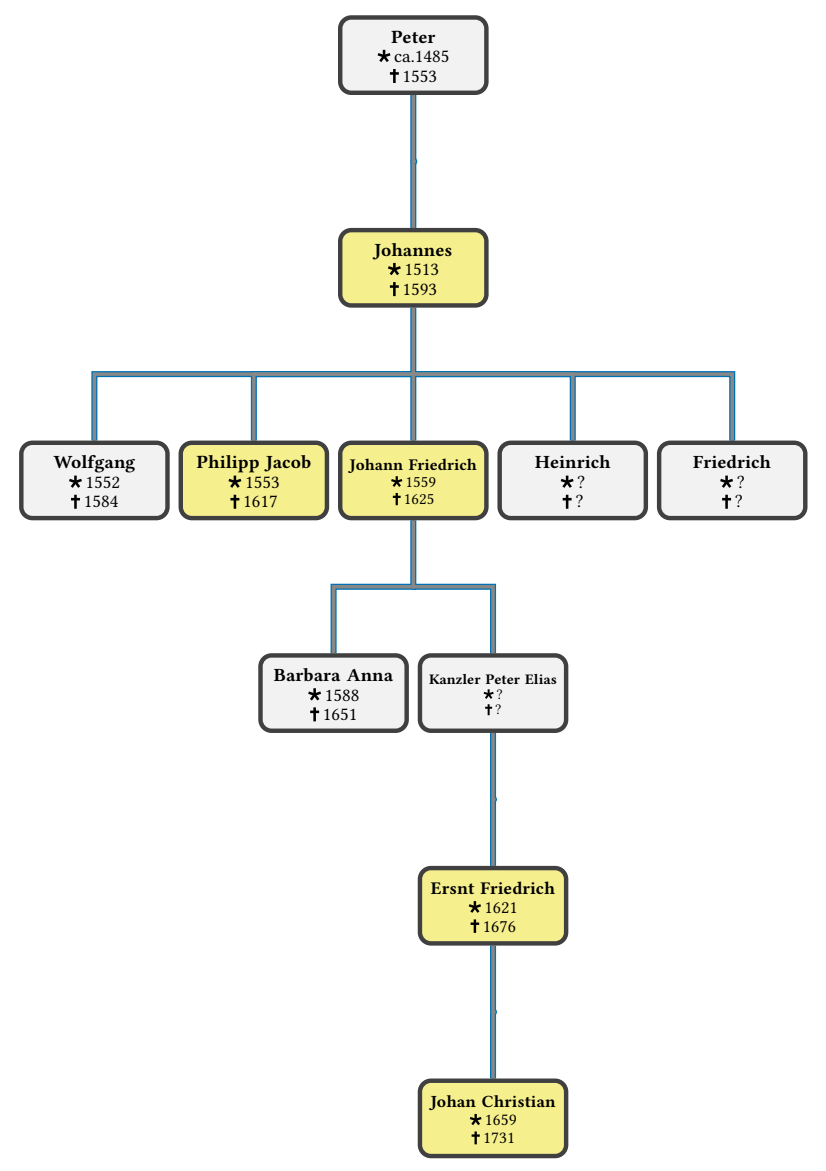

Figure 4: The von Schröter family. Professors at Jena in yellow squares

\section{FAMILIES OF SCHOLARS}

We counted 30 father-son pairs among the professors at the University of Jena. Figure 4 gives one example of a family, the von Schröter family. The genealogy tree is probably incomplete. We have highlighted those who taught at Jena. The three most ancient taught medicine, while their descendants taught law. All of them have published well.

\section{UNIVERSITY NETWORK}

Here we assume that when a professor occupied a position in more than one university over his/her life, this established a link between those universities. The universities with which Jena is linked are displayed in Figure 5. The long distance links seem to shrink over time, except those with the Imperial university of Moscow.

\section{AnecDotes}

Johann Friedrich von Schiller, by far the most famous scholar and professor with the highest rank in our Human Capital Index, was appointed to extraordinary professor in 1789 at the intercession of Johann Wolfgang von Göthe. According to the Neue Deutsche Biographie, however, his engagement at the university did not last long as Schiller did not enjoy academic teaching much.

In 1558 the newly established University of Jena appointed Paul Luther, the third and last son of Dr. Martin Luther, as professor of medicine. The enthusiastic defender of his father's ideas, had objections to the theology of Victorinus Strigel, and left the university soon after to become the personal physician of John Frederick II, Duke of Saxony (Morris 1858). 


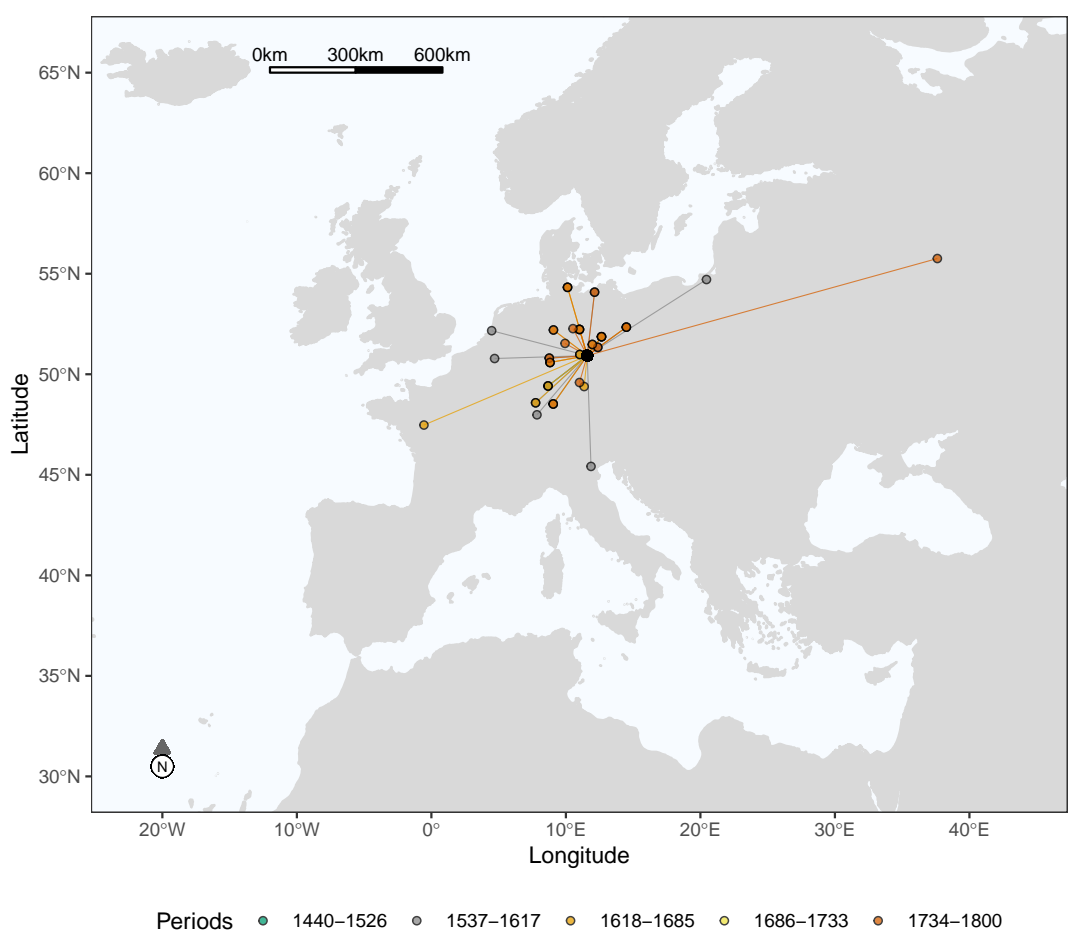

Figure 5: Links between Jena and other universities through scholars' mobility, by period

\section{APPENDIX}

The individual human capital index $q_{i}$ of an individual $i$ is given by:

$$
\begin{aligned}
q_{i}= & -1.76+0.43 \ln (\mathrm{nb} . \text { characters of the longest Wikipedia page }) \\
& +0.40 \ln (\mathrm{nb} . \text { wikipedia pages in different languages })+0.47 \ln (\mathrm{nb} . \text { works in Worldcat }) \\
& +0.46 \ln (\mathrm{nb} . \text { publication languages in Worldcat })+0.47 \ln (\mathrm{nb} \text {. library holdings in Worldcat })
\end{aligned}
$$

We assume that having no Wikipedia page is similar to having one page with a length of 60 characters and that having no Worldcat page is similar to having a page with one work in one language held by one library. The constant -1.76 normalizes $q_{i}$ at 0 when there is neither a Wikipedia page, nor a Worldcat page. The weights $(0.43,0.40$, etc) are obtained from the first principal component of the five indicators (De la Croix et al. 2020).

The notability $Q$ of a university aggregates the $q$ of the top 5 persons who were active in the preceding 25 years using the following formula:

$$
Q=\sqrt{\sum_{i=1}^{5} \frac{1}{5}\left(\frac{q_{i}}{s_{i}}\right)^{2}}
$$

where $s_{i}$ is the number of universities in which $i$ had an appointment.

\section{ACKNOWLEDGMENTS}

This project has received funding from the European Research Council (ERC) under the European Union's Horizon 2020 research and innovation programme under grant agreement No 883033 "Did elite human capital trigger the rise of the West? Insights from a new database of European scholars." Robert Stelter acknowledges financial support from the Max Geldner Foundation.

First version December 3, 2020. Updated February 18, 2021 


\section{REFERENCES}

Applebaum, Wilbur. 2003. Encyclopedia of the scientific revolution: from Copernicus to Newton. New York: Routledge.

De la Croix, David, Frédéric Docquier, Alice Fabre, and Robert Stelter. 2020. "The Academic Market and the Rise of Universities in Medieval and Early Modern Europe (1000-1800)." CEPR Discussion Paper 14509.

Günther, Johannes. 1858. Lebensskizzen der Professoren der Universität fena seit 1558 bis 1858. Jena: Friedrich Mauke.

Hermans, Jos MM, and Marc Nelissen. 2005. Charters of foundation and early documents of the universities of the Coimbra Group. Leuven: Leuven University Press.

Morris, John. 1858. Catharine de Bora; or, Social and Domestic Scenes in the Home of Luther. Philadelphia: Lindsay \& Blakiston. 